\title{
The Interest in Islamic Finance Contracts in Saudi Arabia as Viewed by Google Trends
}

\author{
Wesal M. Aldarabseh ${ }^{1}$ \\ ${ }^{1}$ Department of Finance and Economy, College of Business Administration, Taibah Univesity, Almadinah, Saudi \\ Arabia \\ Correspondence: Wesal M. Aldarabseh, College of Business Administration, Taibah Univesity, Almadinah, Saudi \\ Arabia. Tel: 966-55-730-6743. E-mail: wmaldrabseh@yahoo.com
}

Received: July 13, 2019

doi:10.5539/ijef.v11n9p12
Accepted: August 3, 2019

Online Published: August 8, 2019

URL: https://doi.org/10.5539/ijef.v11n9p12

\begin{abstract}
Several Islamic contracts have been used by Islamic banks to cover the financial needs of their customers. The contracts include Murabahah, Ijarah, Tawarruq, Mudarabah, Musharakah, Salam, and Istisna'. In the current study, the interest in Islamic financial contracts in the past 5 years (2014-2019) in Saudi Arabia as viewed by Google trends was examined. The interest in Murabahah showed increases with the years, whereas decreases in the interest of Tawarruq, Salam Mudarabah were observed in the last years. However, the interest in Ijarah and Istisna' was stable during the examined period. With respect to Musharakah, the interest decreased with years until 2017 then it showed slight increases in 2018 and 2019. Differences in the interest of financial contracts were also observed across different regions of Saudi Arabia. The interest in Ijarah, Tawarruq and Istisna' was higher in Riyadh, whereas the interest in Murabahah and Musharakah was higher in Ha'il than other Saudi regions The present findings can be used by Islamic banks to shape their financing services according to observed interest trends and across different regions of Saudi Arabia.
\end{abstract}

Keywords: Saudi Arabia, Islamic banking, finance, abstract, keywords, introduction

\section{Introduction}

The Kingdom of Saudi Arabia is among the pioneer countries that adopted Islamic banking as a system for financing (Nichita, Kagitci, \& Vulpoi, 2013; Srairi, 2010; Zubairu, Sakariyau, \& Dauda, 2011). The first Islamic bank in Saudi Arabia was established in 1985 (Alanazi \& Lone, 2016). Currently, several full-fledged Islamic banks operate in Saudi Arabia (Aldarabseh, 2019; Aljasser \& Sasidhar, 2015; Khokhar \& Sillah, 2014; Lone \& Ur-Rehman, 2017). The Islamic financial system is characterized by profit-and-loss sharing principle, which is the core of the Islamic financial law (Farooq, 2007; Waemustafa \& Sukri, 2016). The system utilizes several Islamic contracts such as Ijarah, Tawarruq, Murabahah, Mudarabah, Musharakah, Salam, and Istisna' for financing purposes (Abdul-Rahman \& Nor, 2017; Sarker, 1999; Siddiqui, 2008). The utilization of these contracts by Islamic banks should reflect the interest of their customers.

\subsection{Importance of the Problem}

The interest in the Islamic financial contracts and how such interest change with years have not been examined in Saudi Arabia. Such information is valuable to the Islamic Banks to shape their services according to the interest of their customers and to compete in the market. Therefore, the aim of the current study is to examine the interest in Islamic financial contracts in the past 5 years in Saudi Arabia as viewed by google trends. In addition, the interest trends were compared across different regions of Saudi Arabia.

\subsection{Literature Review}

The current study is the first of its kind that examined the trends in the interest of Islamic financial contracts in a given country. Therefore, the literature review will concentrate on the definitions of different Islamic financial contracts and their applications in the Islamic banking system.

Murabahah is a prevalent contract in which the bank provides the cost and profit margin of an asset (Alsayyed, 2010). In this contract, the Islamic bank buys a certain commodity from the seller at the request of the customer, then the bank sells the commodity to the customer at a higher price (Shofawati, 2014; Wulandari, Putri, Kassim, $\&$ Sulung, 2016). The difference between the two prices represents the profit gained by the bank. The customer 
shall then pay the installments of the transaction to the bank as agreed in advance (Shaikh, 2011). Murabahah is widely used to finance purchases of goods, real estate and cars (Abdul-Khaliq, 2014; Wulandari et al., 2016).

Ijarah is another common contract used by Islamic banks. It can be defined as a lease-to-purchase agreement (Billah, 2019). In this contract, the bank purchases and lease services required by the customer for an agreed lease (Lateef, Abdurrazzaq, Shukor, \& Tajudin, 2017). In most of the cases, the contract allows the lessee to choose to own the leased property at the end of the specified lease term (Hussein \& Mat, 2019; Lahsasna, Hassan, \& Ahmad, 2018). Ijarah is used primarily by the bank to finance housing, cars and equipment (Baber, 2017; Jalil \& Rahman, 2010; Prabowo \& Jamal, 2017).

Tawarruq is a contract in which the bank buys a commodity, then the bank sells it to the customer in installments. The customer then sells the commodity in less to a third party to get cash. If the customer authorizes the bank to sell the commodity, then this form is called "organized Tawarruq" (Al-Zuhaili, 2006; Mahyudin \& Seman, 2018). Tawarruq is used by some banks to provide cash money to customers to cover urgent needs of the customers such as university fees, medical care costs, travel expenses and others (Mohamad \& Ab Rahman, 2014).

Mudarabah is a contract between two parties in which one party brings capital and the other provides the labor and skill for investing in a project. The earnings are shared between the two parties as indicated by the contract (Bidabad, 2014). In Islamic banking, the capital is provided by the bank and the labor/skill is provided by the customer (Amelia \& Hardini, 2017). Among the suggested uses of Mudarabah in Islamic banking are small and medium project financing, interbank investment, investment deposits, and so on (Shaharuddin, 2010; Zain, Yaacob, Ahmad, Zakaria, \& Ghani, 2014)

Musharakah is a partnership financing in which partners share in the profits and losses of the project (Usmani, 1999). In Islamic banking, the bank provides part of the capital, which are intermingled with the other funding sources of the business enterprise (Adela, 2018). The profits/losses are distributed among the bank and other partners in predetermined ratios as indicated by the contract.

Salam is a contract that can be defined as an advance payment for a specific a commodity to be delivered to the bank at a specified future date and place (Mohammed, Ogunbado, \& Bashir, 2016). The contract is used by some Islamic banks to finance agricultural and utility products (Kaleem, 2009; Saiti, 2018).

Istisna' is a contract between two parties in which one party agrees to manufacture and deliver specified items at a pre-determined future time at an agreed price (Zarka, 1997). For example, the Islamic bank undertakes to support the production of specific item (s), at a predetermined price/fixed date of delivery (Muhammad \& Chong, 2007). The contract is used to finance industrial projects such as construction of buildings, infrastructures, equipment and machines (Zarka, 1997).

\subsection{Research Hypothesis}

In the current study, we hypothesized that the interest in Islamic financial contracts in Saudi Arabia changes with the years. In addition, the interest in contracts might vary across different regions of the Kingdom.

\section{Method}

Google Trends service (www.google.com/trends) was used to generate the trend in the interest of Islamic financial contracts in Saudi Arabia in the past 5 years. Google Trends is a free service offered by Google that displays the relative frequency of the entrance of a particular word (term) in the search engine to the total search volume in a given time/region. The generated data are expressed as relative search volume scaled ( 0 to 100$)$ to the week where the highest number of searches was performed for that given word. It is worth to mention that Google Trends removes repeated searches from the same party over a short period to produce a more accurate trend. In addition, it only presents trends of popular terms as low volumes appear as zero (Choi \& Varian, 2012).

Search queries indicative of Arabic Islamic financial contract terms (Ijarah, Tawarruq, Murabahah, Mudarabah, Musharakah, Salam, Istisna'and Sukuk) were analyzed in the different regions of Saudi Arabia in the past 5 years from June 2014 to June 2019. The Included regions were Riyadh, Qassim, Makkah, Madinah, Tabuk, Eastern Province, Bahah, Jizan, 'Asir, Najran, Jawf, Ha'il and Northern Province.

To simplify visual comparisons across years, relative search volumes across the years were downloaded in the form of EXCEL files and data were plotted in column format as mean \pm standard error mean. In addition, data were statistically analyzed using Prism Graphpad software. For multiple groups, ANOVA followed by the Tukey post hoc test were utilized. $\mathrm{P}$ values of $<0.05$ were considered significant.

\section{Results and Discussion}

The current study examined the interest in the different Islamic contracts in Saudi Arabia in the past 5 years 
using Google trends. Among the examined contracts are Murabahah, Ijarah, Tawarruq, Mudarabah, Musharakah, Salam, and Istisna'.

Figure 1A showed the interest in the Murabahah contract in the past 5 years. An increase in the search volume was observed with years. The mean relative search volumes of 2018 and 2019 were significantly higher than that of previous years (, P $<0.001$, Figure 1B). In addition, No significant differences in mean search volumes were detected between 2014, 2015 and 2016 (P > 0.05). When the different regions of Saudi Arabia were considered, Ha'il region showed the highest relative search volumes, followed by Jizan, Qassim, Madinah, Riyadh, 'Asir, Eastern Province, and Makkah (Table 1). However, no search volumes were available from Tabuk, Najran, Jawf and Northern Province (Table 1). In Saudi Arabia, Murabaha contract is very common and is used by Islamic banks for personal finance to cover purchases of goods, real estate, cars and others (Al-Islambuli, 2005).

A)

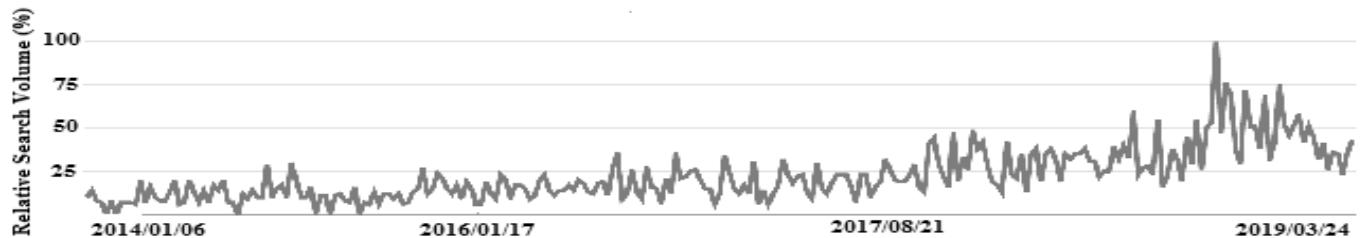

B)

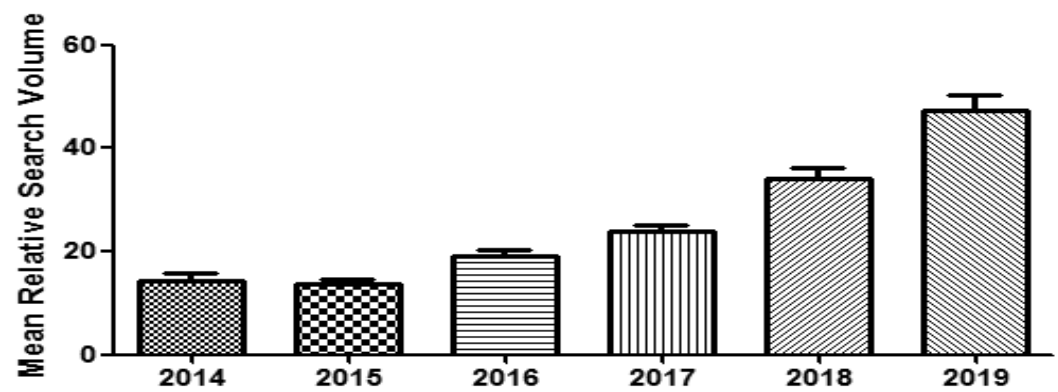

Figure 1. Interest in Murabahah contract in the past 5 years in Saudi Arabia. A) As revealed in Google Trends. B) Average of the relative search volumes (mean \pm SEM)

Table 1. Interest in Islamic financial contracts in Saudi Arabia according to Region in the past 5 years

\begin{tabular}{lccccccc}
\hline Region & Murabahah & Ijarah & Tawarruq & Mudarabah & Musharakah & Salam & Istisna' \\
\hline Riyadh & 36 & 100 & 100 & 88 & 78 & 87 & 100 \\
Qassim & 47 & - & - & - & 82 & 99 & - \\
Makkah & 28 & 87 & 85 & 100 & 71 & 98 & 43 \\
Madinah & 39 & - & & 98 & - & 99 & - \\
Tabuk & - & - & & & 76 & 82 & - \\
Eastern Province & 30 & 66 & 69 & 65 & 66 & 74 & - \\
Bahah & - & - & - & - & - & - & - \\
Jizan & 60 & - & - & - & 87 & 60 & - \\
'Asir & 36 & - & - & - & 88 & 83 & - \\
Najran & - & - & - & - & - & 100 & - \\
Jawf & - & - & - & - & 100 & 73 & - \\
Ha'il & 100 & - & - & - & 83 & 68 & - \\
Northern Province & - & - & - & - & & & - \\
\hline
\end{tabular}

With respect to Ijarah contract, search volume was lower in 2014 compared to other years (Figure 2). The interest stayed stable from 2015 to 2019. The search volumes were highest in Riyadh, followed by Makkah and Eastern Province. However, no search volumes were available from other Saudi regions (Table 1). This contract is used by Islamic banks in Saudi Arabia to finance housing (Sidawi, 2014), cars (Ehsan Wahla, Hasan, \& Bhatti, 2018), utility services (Aldarabseh, 2019). Ijarah takes different forms that include regular Ijarah, Sukuk Ijarah and Al-Ijarah Al-Muntahiyah bi Al-Tamlik (Hussein \& Mat, 2019; Lahsasna et al., 2018). 
A)

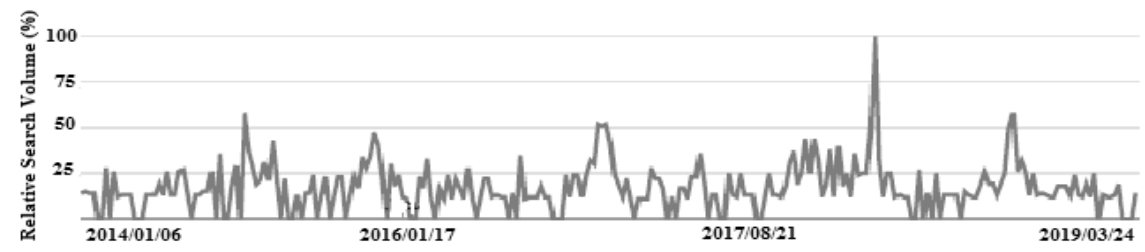

B)

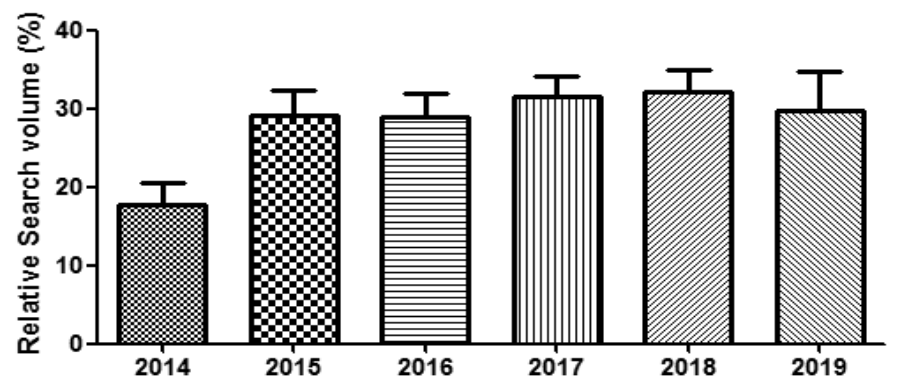

Figure 2. Interest in Ijarah contract in the past 5 years in Saudi Arabia. A) As revealed in Google Trends. B)

Average of the relative search volumes (mean \pm SEM)

A) ร

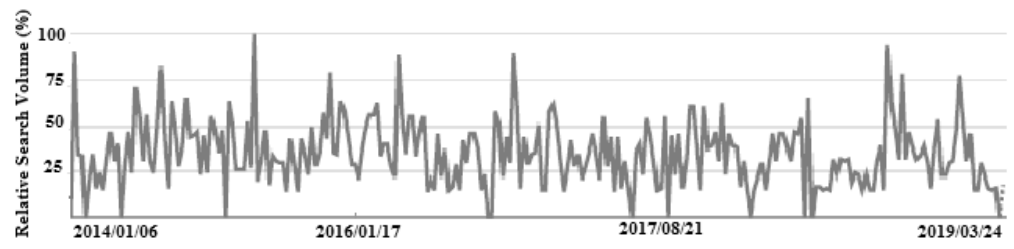

B)

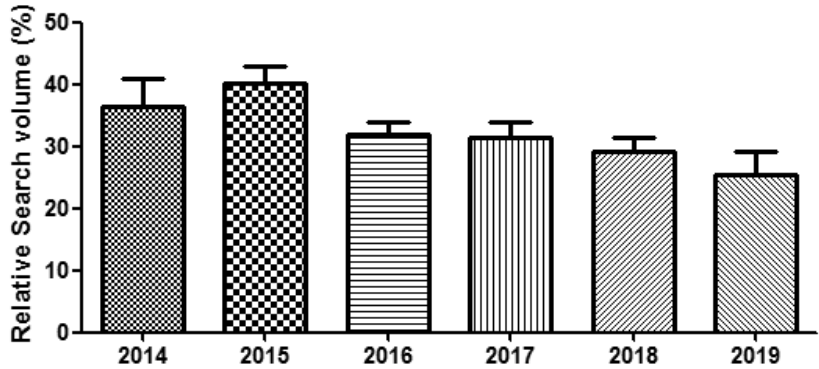

Figure 3. Interest in Tawarruq contract in the past 5 years in Saudi Arabia. A) As revealed in Google Trends. B) Average of the relative search volumes (mean \pm SEM)

The interest in Tawarruq contract in the past 5 years is shown in Figure 3. A decrease in the search volume was observed with years. The mean relative search volumes of 2018 and 2019 were significantly lower than that of 2015 ( $\mathrm{P}<0.01$, Figure 3B). No significant differences in mean search volumes were detected between other examined years $(\mathrm{P}>0.05)$. When the different regions of Saudi Arabia were considered, the Riyadh region showed the highest relative search volumes, followed by Makkah and Eastern Province (Table 1). However, no search volumes were available from other Saudi regions (Table 1). Tawarruq is a widely used contract in Saudi Arabia by Islamic banks to enable the customers to get cash money to cover customers' utility services (Al-Shalhoob, 2007; Ismon, 2012). There are contradictory views on the utilization of organized Tawarruq. While some jurists consider this contract as "Halal", others view it as "Haram" and should not be used by Islamic banking (Ahmad et al., 2017; Khnifer, 2010).

With respect to Mudarabah contract (Figure 4), the relative search volumes in 2014 and 2015 were significantly higher than recent years $(\mathrm{P}<0.001$, Figure 4B). In addition, no significant differences were detected between search volumes of 2016, 2017, 2018 and 2019 years $(\mathrm{P}>0.05)$. With respect to regions, the search volumes were highest in Makkah, followed by Madinah, Riyadh, and Eastern Province. However, no search volumes were available from other Saudi regions (Table 1). Mudarabah is used by banks in Saudi Arabia to finance small and medium businesses, interbank investment and others (Al-Shamrani, 2014; Archer \& Karim, 2009; BinTawim, 
2011).

A)

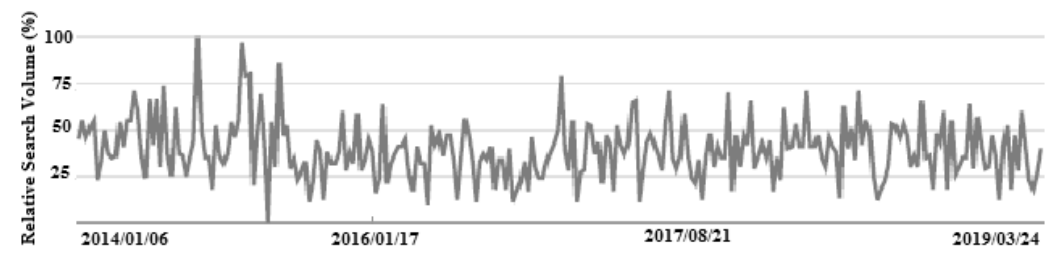

B)

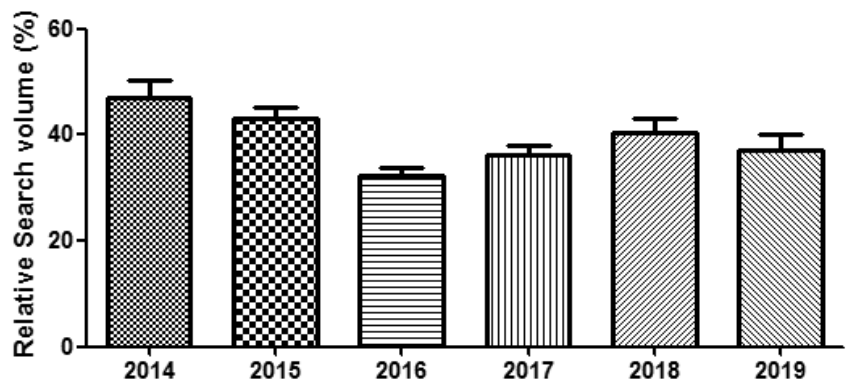

Figure 4. Interest in Mudarabah contract in the past 5 years in Saudi Arabia. A) As revealed in Google Trends. B) Average of the relative search volumes (mean \pm SEM)

Figure 5 showed the interest trend in the Musharakah contract. The search volume decreased with years until 2017 then it showed a slight increase in the following years (Figure 5B). Significant differences between 2014 and most of other examined years $(2016,2017$, and 2018, P $<0.01)$ were observed. When the different regions of Saudi Arabia were considered, Ha'il region showed the highest relative search volumes (Table 1). Comparable search volumes were observed in Riyadh, Qassim, Makkah, Tabuk, Eastern Province, Jizan, 'Asir, Najran, Northern Province. However, no search volumes were available from Jawf, Bahah and Madinah (Table 1). Musharakah contract is used in Saudi Arabia to finance manufacturing businesses (Al-Shamrani, 2014; Nichita et al., 2013) and home financing (Sidawi, 2009). In general, Musharakah is not widely used by Islamic banks because it is associated with a higher risk compared to other Islamic financial contracts (Jaffar, Ismail, Maad, \& Samson, 2012).

The interest in Salam contract is shown in Figure 6. Significant increases in the search volume were observed in 2014 and 2015 years $(\mathrm{P}<0.01$, Figure 6B). No significant differences in mean search volumes were detected between other examined years $(2016,2017,2018$ and 2019, P > 0.05). When the different regions of Saudi Arabia were considered, Jawf region showed the highest relative search volumes. The other regions showed comparable search volumes (Table 1). Salam is mainly used by Islamic banks to finance agricultural activities (BinTawim, 2011; Kaleem, 2009; Saiti, 2018).
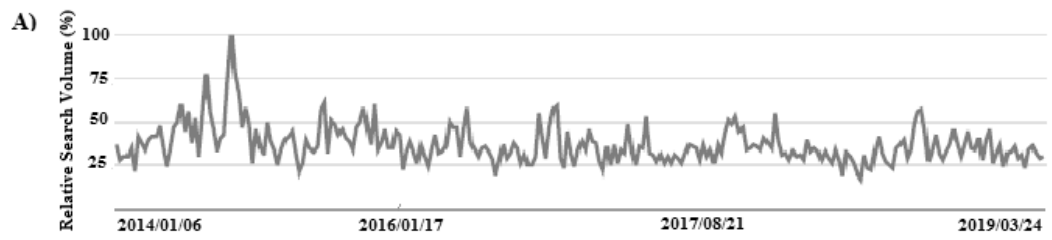

B)

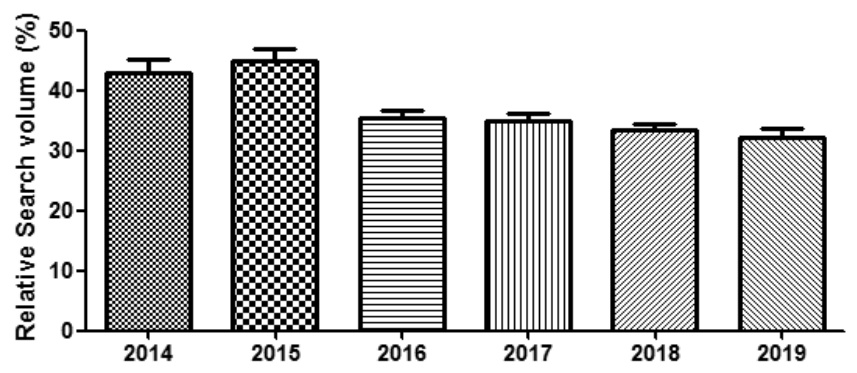

Figure 5. Interest in Musharakah contract in the past 5 years in Saudi Arabia. A) As revealed in Google Trends. B) Average of the relative search volumes (mean \pm SEM) 


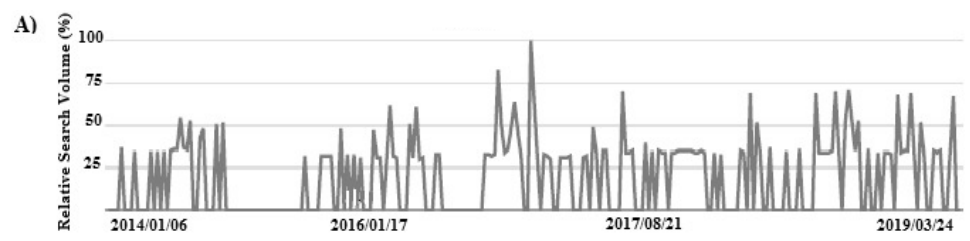

B)

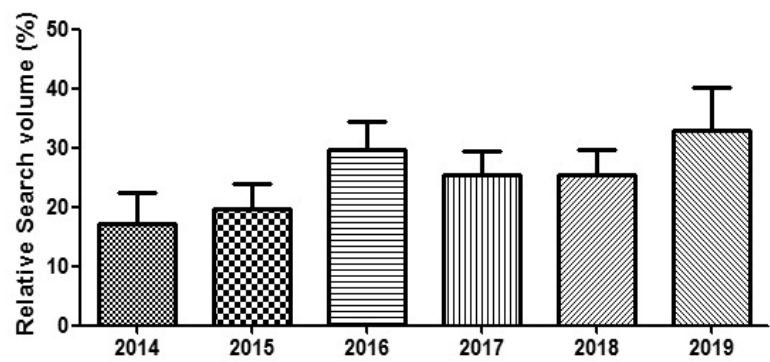

Figure 6. Interest in Salam contract in the past 5 years in Saudi Arabia. A) As revealed in Google Trends. B) Average of the relative search volumes (mean $\pm \mathrm{SEM}$ ).

The last examined contract is Istisna' (Figure 7). Similar research volumes were observed in the examined time period (past 5 years, Figure 7B, P > 0.05). The search volumes were highest in Riyadh, followed by Makkah. However, no search volumes were available from other Saudi regions (Table 1). Istisna' is used in Saudi Arabia and other countries to finance construction of buildings and infrastructures, equipment, machines, and others (Hasmawati, 2019; Rarasati, 2014; Zarka, 1997).

The described trend changes in the interest of Islamic financial contracts might be used by Islamic banks in Saudi Arabia to shape their financing services according to interest trends. In addition, the observed differences in the interest of Islamic contracts across different regions of Saudi could be used by banks to provide region-specific financial services. This will enhance the ability of Islamic banks to compete in the market.

Among the limitations of the current study is that the interest in Islamic contracts was examined using Google trends. The present findings need to be confirmed using actual field studies.

A)

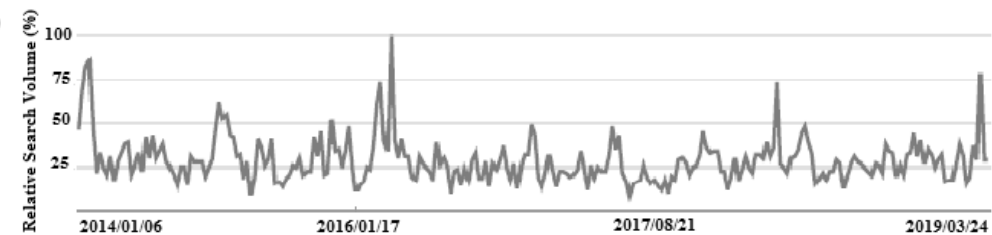

B)

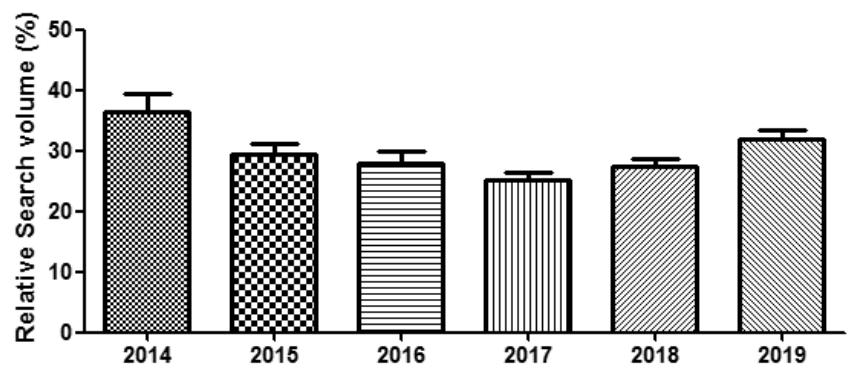

Figure 7. Interest in Istisna' contract in the past 5 years in Saudi Arabia. A) As revealed in Google Trends. B) Average of the relative search volumes (mean \pm SEM)

\section{Conclusion}

The interest in Islamic financial contracts in Saudi Arabia in the past 5 years was described using Google trends. An increase in Murabahah interest with years was observed. On the other hand, decreases in the interest of Tawarruq, Salam, and Mudarabah were observed in the last years. The interest in Ijarah and Istisna' was stable 
during the examined period. With respect to Musharakah, the interest decreased with years until 2017 then it showed slight increase in the following years. The interest in contracts was also different across regions of Saudi Arabia. For example, the interest in Ijarah, Tawarruq and Istisna' was higher in Riyadh than other regions. The interest in Murabahah and Musharakah was higher in Ha'il than other Saudi regions. The observed trend changes in the interest of Islamic financial contracts might be used by Islamic banks in Saudi Arabia to shape their financing services and to enhance their ability to compete in the market. Future field studies are needed to confirm the present findings observed using Google trends.

\section{Acknowledgments}

The author would like to thank faculty members and students at College of Business Administration at Taibah University for their support.

\section{References}

Abdul-Khaliq, S. (2014). Comparison study of Murabaha and Istisnaa in Islamic banking in Jordan. Interdisciplinary Journal of Contemporary Research in Business, 5(9), 603-612.

Abdul-Rahman, A., \& Nor, S. M. (2017). Challenges of profit-and-loss sharing financing in Malaysian Islamic banking. Geografia: Malaysian Journal of Society and Space, 12(2).

Adela, H. (2018). The impact of Musharakah financing on the monetary policy in the Islamic economy. Review of Economics and Political Science, 3(3/4), 139-152. https://doi.org/10.1108/REPS-10-2018-014

Ahmad, E. F., Shihama, M., Tarmizi, M., Ashikin, N., Jibril, S. M., Djama, S. I., \& Muneeza, A. (2017). Tawarruq as a product for financing within the Islamic banking system: A case study of Malaysian Islamic banking system. International Journal of Management and Applied Research, 4(1), 31-43. https://doi.org/10.18646/2056.41.17-004

Alanazi, E., \& Lone, F. (2016). Social Satisfaction towards Islamic Banking in Saudi Arabia: A Survey. Asian Social Science, 12(1), 182-190. https://doi.org/10.5539/ass.v12n1p182

Aldarabseh, W. M. (2019). Customer Satisfactions on Islamic Banking Services in Almadinah City, Saudi Arabia. Asian Journal of Economics, Business and Accounting, 1-8. https://doi.org/10.9734/ajeba/2019/v11i430136

Al-Islambuli, A. M. K. (2005). The Murabahah, Inah and Tawarroq within Assets of the Bank and its Liabilities. Journal of King Abdulaziz University: Islamic Economics, 18(1), 59-68. https://doi.org/10.4197/islec.18-1.8

Aljasser, I. A., \& Sasidhar, B. (2015). Satisfaction Perceptions Differences of Customers of Banks in Saudi Arabia Based on Gender. Journal of Economics, Management and Trade, 279-287. https://doi.org/10.9734/BJEMT/2015/16858

Alsayyed, N. (2010). The uses and misuses of commodity murabaha: Islamic Economic Perspective.

Al-Shalhoob, S. (2007). Organized Tawarruq in Islamic Law: A Study of Organized Tawarruq as Practiced in the Financial Institutions in Saudi Arabia. Paper presented at the A paper presented at IIUM International Conference on Islamic Banking \& Finance.

Al-Shamrani, A. S. (2014). Islamic financial contracting forms in Saudi Arabia: Law and practice.

Al-Zuhaili, W. (2006). Tawarruq, Its Essence And Its Types: Mainstream Tawarruq And Organized Tawarruq.

Amelia, E., \& Hardini, E. F. (2017). Determinant of Mudharabah Financing: A Study at Indonesian Islamic Rural Banking. Etikonomi, 16(1). https://doi.org/10.15408/etk.v16i1.4638

Archer, S., \& Karim, R. A. A. (2009). Profit-sharing investment accounts in Islamic banks: Regulatory problems and possible solutions. Journal of Banking Regulation, 10(4), 300-306. https://doi.org/10.1057/jbr.2009.9

Baber, H. (2017). A comparative study of Islamic housing finance models and issues. Qualitative Research in Financial Markets, 9(2), 168-180. https://doi.org/10.1108/QRFM-12-2016-0053

Bidabad, B. (2014). Mudarabah Financial Sharing (MFS). Journal of Islamic Economics, Banking and Finance, 113(3250), 1-13. https://doi.org/10.12816/0025697

Billah, M. M. S. (2019). Islamic Lease Financing (Al-Ijarah). Islamic Financial Products, 227-241. https://doi.org/10.1007/978-3-030-17624-2_17

BinTawim, S. S. (2011). Performance analysis of Islamic banking: Some evidence from Saudi Arabian banking sector. Ritsumeikan Asia Pacific University.

Choi, H., \& Varian, H. (2012). Predicting the Present with Google Trends. Economic Records, 88(s1), 8. 
https://doi.org/10.1111/j.1475-4932.2012.00809.x

Ehsan Wahla, A., Hasan, H., \& Bhatti, M. I. (2018). Measures of customers' perception of car Ijarah financing. Journal of Islamic Accounting and Business Research, 9(1), 2-16. https://doi.org/10.1108/JIABR-10-2015-0051

Farooq, M. O. (2007). Partnership, equity-financing and Islamic finance: Whither profit-loss sharing? Review of Islamic Economics (Special Issue), 11, 67-88.

Hasmawati, A. (2019). Potential application of Istisna' financing in Malaysia. Qualitative Research in Financial Markets, 11(2), 211-226. https://doi.org/10.1108/QRFM-07-2018-0083

Hussein, R., \& Mat, K. A. (2019). Forms of Al-Ijarah Al-Muntahiyah bi Al-Tamlik and its Jurisprudential Adaptation. International Journal of Academic Research in Business and Social Sciences, 9(3). https://doi.org/10.6007/IJARBSS/v9-i3/5715

Ismon, N. Y. B. (2012). Legality of Tawarruq in Islamic Finance. Tazkia Islamic Finance and Business Review, $7(1)$.

Jaffar, M. M., Ismail, R., Maad, H. A., \& Samson, A. A. (2012). The application of new musyarakah model in Islamic banking products. Paper presented at the 2012 International Conference on Statistics in Science, Business and Engineering (ICSSBE). https://doi.org/10.1109/ICSSBE.2012.6396559

Jalil, A., \& Rahman, M. K. (2010). Financial transactions in Islamic Banking are viable alternatives to the conventional banking transactions. International Journal of Business and Social Science, 1(3).

Kaleem, A. (2009). Application of Islamic banking instrument (Bai Salam) for agriculture financing in Pakistan. British Food Journal, 111(3), 275-292. https://doi.org/10.1108/00070700910941471

Khnifer, M. (2010). Maslaha and the permissibility of organized tawarruq. Opalesque Islamic Finance Intelligence, (8), 6-11. https://doi.org/10.2139/ssrn.1712061

Khokhar, I., \& Sillah, B. (2014). Consumer Perceptions on Islamic Banks: The Case of Saudi Arabia. The International Association of Islamic Banks Karachi, 31(4), 70-81.

Lahsasna, A., Hassan, M. K., \& Ahmad, R. (2018). Ijarah Sukuk and Forward Lease Sukuk-Case Study. Forward Lease Sukuk in Islamic Capital Markets, 187-205. https://doi.org/10.1007/978-3-319-94262-9_9

Lateef, A. W., Abdurrazzaq, A. A., Shukor, S. A., \& Tajudin, A. A. (2017). Maqasid Al-Shari'ah in Ijarah (Leasing) Contract of Islamic Banking System. Journal of Islamic Finance, 6(2), 038-044.

Lone, F., \& Ur-Rehman, A. (2017). Customer Satisfaction in Full-Fledged Islamic Banks and Islamic Banking Windows: A Comparative Study. Journal of Internet Banking and Commerce, 22(S7), 1-20.

Mahyudin, M. I., \& Seman, A. C. (2018). The Application of Bay’Al-Tawarruq in Islamic Banking Institutions in Malaysia: A Study of Bank Muamalat Malaysia Berhad. New Developments in Islamic Economics, 169-179: Emerald Publishing Limited. https://doi.org/10.1108/978-1-78756-283-720181011

Mohamad, N., \& Ab Rahman, A. (2014). Tawarruq application in Islamic banking: A review of the literature. International Journal of Islamic and Middle Eastern Finance and Management, 7(4), 485-501. https://doi.org/10.1108/IMEFM-10-2013-0106

Mohammed, A. I., Ogunbado, A. F., \& Bashir, A. (2016). The Viability of Salam Finance In The Growth Of Agricultural Production In Kano State, Nigeria. Asian Journal of Multidisciplinary Studies, 4(12), 6.

Muhammad, M. Z., \& Chong, R. (2007). The contract of bay Al-Salam and Istisna in Islamic commercial law: Comparative analysis. Labuan e-Journal of Muamalat and Society, 1(1), 8.

Nichita, M., Kagitci, M., \& Vulpoi, M. (2013). İslamic banking system. The case of the kingdom of Saudi Arabia. Romanian Economic and Business Review, 211.

Prabowo, B. A., \& Jamal, J. B. (2017). Concept And Application Of Akad Wakalah In Murabaha Financing In Islamic Banking (A Comparative Study Between Indonesia And Malaysia). Diponegoro Law Review, 2(1), 1-14. https://doi.org/10.14710/dilrev.2.1.2017.1-14

Rarasati Ayomi, D. (2014). The Opportunity for Implementing Islamic Project Financing to the Indonesian Infrastructure Development. In B. Trigunarsyah (Ed.), The Developing Role of Islamic Banking and Finance: From Local to Global Perspectives (Vol. 95, pp. 103-116). Emerald Group Publishing Limited. https://doi.org/10.1108/S1569-3759(2014)0000095015 
Saiti, B. (2018). Financing agricultural activities in Afghanistan: A proposed salam-based crowdfunding structure. ISRA International Journal of Islamic Finance, 10(1), 52-61. https://doi.org/10.1108/IJIF-09-2017-0029

Sarker, M. A. A. (1999). Islamic business contracts, agency problem and the theory of the Islamic firm. International Journal of Islamic Financial Services, 1(2), 12-28.

Shaharuddin, A. (2010). A study on Mudarabah in Islamic law and its application in Malaysian Islamic banks.

Shaikh, S. A. A. (2011). A critical analysis of Mudarabah \& a new approach to equity financing in Islamic finance. Journal of Islamic Banking \& Finance, Forthcoming.

Shofawati, A. (2014). Murabahah financing in Islamic banking: Case study in Indonesia. Paper presented at the Proceedings of 5th Asia-Pacific Business Research Conference 17-18, Hotel Istana, Kuala Lumpur, Malaysia.

Sidawi, B. (2009). Hindrances to the financing of affordable housing in Kingdom of Saudi Arabia. Emirates Journal for Engineering Research, 14(1), 73-82.

Sidawi, B. (2014). An evaluation of the performance of the housing finance system in the Kingdom of Saudi Arabia. International Journal of Housing Markets and Analysis, 7(2), 156-174. https://doi.org/10.1108/IJHMA-11-2012-0057

Siddiqui, A. (2008). Financial contracts, risk and performance of Islamic banking. Managerial Finance, 34(10), 680-694. https://doi.org/10.1108/03074350810891001

Srairi, S. A. (2010). Cost and profit efficiency of conventional and Islamic banks in GCC countries. Journal of Productivity Analysis, 34(1), 45-62. https://doi.org/10.1007/s11123-009-0161-7

Usmani, M. T. (1999). The concept of musharakah and its application as an Islamic method of financing. Arab Law Quarterly, 14(3), 203-220. https://doi.org/10.1163/026805599125826435

Waemustafa, W., \& Sukri, S. (2016). Systematic and unsystematic risk determinants of liquidity risk between Islamic and conventional banks.

Wulandari, P., Putri, N. I. S., Kassim, S., \& Sulung, L. A. (2016). Contract agreement model for murabahah financing in Indonesia Islamic banking. International Journal of Islamic and Middle Eastern Finance and Management, 9(2), 190-204. https://doi.org/10.1108/IMEFM-01-2015-0001

Zain, M. N. M., Yaacob, S. E., Ahmad, A. A., Zakaria, Z., \& Ghani, N. A. R. N. A. (2014). Gold Investment Application through Mudarabah Instruments in Malaysia: Analysis of Gold Dinar as Capital. Asian Social Science, 10(7), 173. https://doi.org/10.5539/ass.v10n7p173

Zarka, A. (1997). Istisna' Financing of Infrastructure Projects. Islamic Economic Studies, 4(2), 8.

Zubairu, U. M., Sakariyau, O. B., \& Dauda, C. K. (2011). Social reporting practices of Islamic banks in Saudi Arabia. International Journal of Business and Social Science, 2(23).

\section{Copyrights}

Copyright for this article is retained by the author(s), with first publication rights granted to the journal.

This is an open-access article distributed under the terms and conditions of the Creative Commons Attribution license (http://creativecommons.org/licenses/by/4.0/). 